\title{
Synthesis of the Benzodioxane Portion of Haedoxans
}

\author{
Fumito IshIBASHI and Eiji TaNIGUCHI* \\ Department of Agricultural Chemistry, Faculty of Agriculture, \\ Kyushu University, Hakozaki 6-10-1, Higashi-ku. \\ Fukuoka 812, Japan \\ Received December 12, 1988
}

\begin{abstract}
$\left(2 R^{*}, 3 R^{*}\right)$-6-Formyl-7-methoxy-3-methoxymethyl-2-(3',4'-methylenedioxyphenyl)-2,3-dihydro1,4-benzodioxine, a starting material for haedoxan synthesis, was synthesized from 2,4dihydroxybenzaldehyde.
\end{abstract}

A 2,3-dihydro-1,4-benzodioxine framework is involved in biologically active lignans such as silybin, ${ }^{1)}$ americanin ${ }^{2)}$ and cleomiscosin $\mathrm{A},{ }^{3)}$ but is still rare in natural products. Haedoxans are novel insecticidal neolignans, which involve a benzodioxane framework in their molecules as illustrated in Fig. 1 (depicted inside the dotted lines). The regiochemistry of the benzodioxane portion of haedoxan $\mathrm{A}$ was determined as 1 on the basis of ${ }^{13} \mathrm{C}-{ }^{1} \mathrm{H}$ longrange selective proton decoupling (LSPD) experiments, and this assignment was supported by the LSPD spectra of trans-6-methoxy-2methoxymethyl-3-(3',4'-methylenedioxyphenyl)-2,3-dihydro-1,4-benzodioxine (2a) and trans-6-methoxy-3-methoxymethyl-2(3',4'-methylenedioxyphenyl)-2,3-dihydro-1,4benzodioxine (3) which were unambiguously synthesized. ${ }^{4)}$ The potent insecticidal activity of haedoxan A prompted our interest in its total synthesis, as well as its derivation and structure-activity relationship. In this paper, details of the preparation of benzodioxanes $\mathbf{2 a}$ and $\mathbf{3}$, and benzodioxane aldehyde $\mathbf{4}$, which is a starting material for the syntheses of haedoxans, is reported.

A method developed for the unambiguous synthesis of a 2,3-disubstituted benzodioxane portion of silybin ${ }^{5,6)}$ was employed with a little modification for the present synthesis of $\mathbf{2 a}$ (Fig. 2). An alternative synthesis of benzodioxane skeleton has recently been reported in the total synthesis of americanin A. ${ }^{\text {) }}$

Regioselective methylation of the para hydroxyl group of 2,4-dihydroxybenzaldehyde (6), using methyl iodide and potassium car-

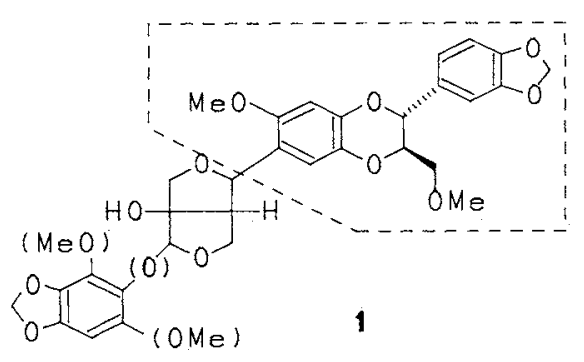<smiles>COCC1Oc2ccc(OC)cc2O[C@H]1c1ccc2c(c1)OCO2</smiles><smiles>COC[C@H]1Oc2ccc(OC)cc2OC1c1ccc2c(c1)OCO2</smiles>

Fig. 1. 
<smiles>C=CC=C1CC1</smiles><smiles>CCOC(=O)C(Oc1cc(C=O)ccc1OC)C(Oc1ccc(OC)c(OC)c1)c1ccc(OC)c(OC)c1</smiles>

5

Fig. 2.
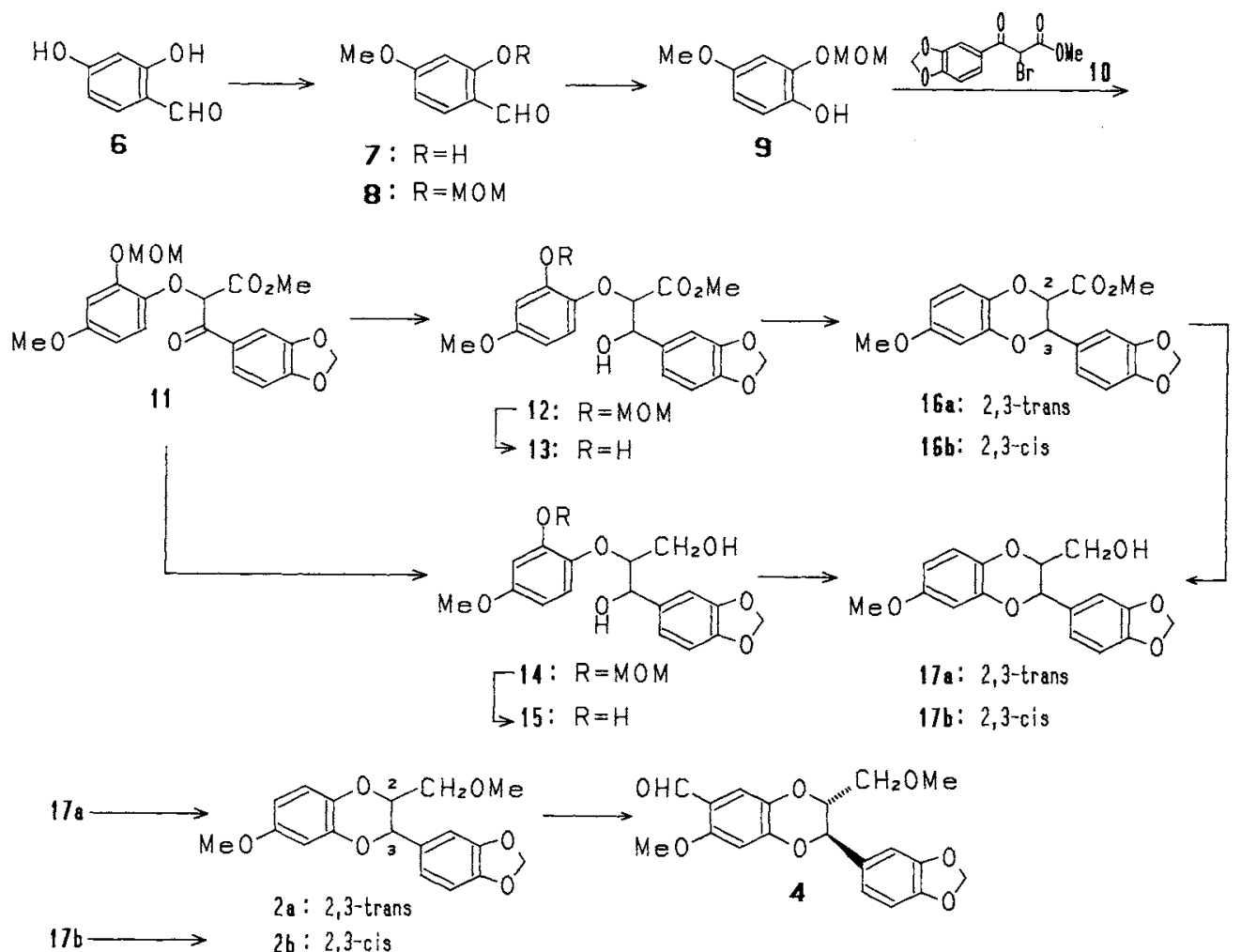

Fig. 3.

bonate $^{8)}$ in refluxing acetone, afforded 2-hydroxy-4-methoxybenzaldehyde (7) in an appreciable yield. Protection of the ortho hydroxyl group as its methoxymethyl (MOM) ether with chloromethyl methyl ether, potassium hydroxide and a catalytic amount of dibenzo-18-crown- $6^{5)}$ in acetonitrile gave 8 in $79 \%$ yield. The aldehyde was subjected to the Baeyer-Villiger oxidation with $m$-chloroper- benzoic acid (MCPBA)-potassium fluoride complex $^{9)}$ in methylene chloride, and the resulting formate was immediately hydrolyzed in an equeous alkaline medium to afford phenol 9 in $77 \%$ yield.

Etherification of 9 with bromide 10 , obtained by the bromination of methyl 3,4methylenedioxybenzoylacetate ${ }^{10)}$ in the presence of potassium tert-butoxide and a catalyt- 
Table I. DehydRative Cyclizations

\begin{tabular}{cclcc}
\hline Run & Compound & \multicolumn{1}{c}{ Conditions } & Products $(\%$ yield $)$ & trans: cis \\
\hline 1 & $\mathbf{1 3}$ & $\mathrm{PPA}, \mathrm{r.t.}$ & $\mathbf{1 6 a}, \mathbf{b}(59)$ & $75: 25$ \\
2 & $\mathbf{1 3}$ & $\mathrm{P}_{2} \mathrm{O}_{5} / \mathrm{CH}_{2} \mathrm{Cl}_{2}$ & $\mathbf{1 6 a}, \mathbf{b}(69)$ & $48: 52$ \\
3 & $\mathbf{1 3}$ & $\mathrm{KHSO}_{4} / \mathrm{CH}_{2} \mathrm{Cl}_{2}$ & $\mathbf{1 6 a}, \mathbf{b}(56)$ & $54: 46$ \\
4 & 15 & $\mathbf{P P A}, \mathrm{r.t.}$ & $\mathbf{1 7 a}, \mathbf{b}(60)$ & $88: 12$ \\
5 & $\mathbf{1 5}$ & Amberlist-15/PhMe & $\mathbf{1 7 a}, \mathbf{b}(58)$ & $77: 23$
\end{tabular}

a The ratio was determined by HPLC.

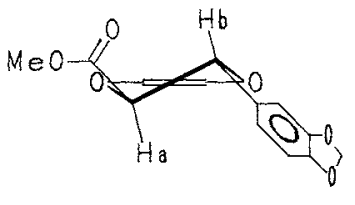

$16 a$

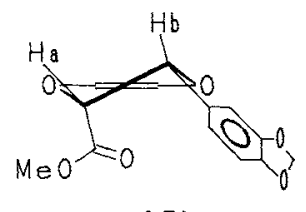

$16 b$

Fig. 4.

ic amount of dibenzo-18-crown- $6^{5)}$ in acetonitrile gave 11 in $94 \%$ yield. Reduction of the keto-ester using a half molar equivalent of sodium borohydride in a mixture of ethanol and tetrahydrofuran $(1: 1)$ produced hydroxy ester 12 along with diol 14 in $53 \%$ and $27 \%$ yields, respectively. When an equimolar equivalent of the reagent was used, triol 15 was obtained as the major product $(73 \%$ yield $)$ after hydrolysis of methoxymethyl ether $\mathbf{1 4}$.

Hänsel et al. reported that ethyl 3-( $3^{\prime}, 4^{\prime}-$ dimethoxyphenyl)-2-[4"'-formyl-2" -(methoxymethoxy)phenoxy]-3-hydroxypropionate (5) was easily cyclized to the corresponding benzodioxane (trans/cis $=75 / 25$ ) in $2 \%$ sulfuric acid in acetic acid (Fig. 2). ${ }^{6}$ Under these conditions, however, congener 12 was decomposed to give a mixture of unidentified products. Dehydrative cyclizations of diol $\mathbf{1 3}$ and triol 15 were tried under several conditions (Table I). The cyclization by polyphosphoric acid (PPA) was best accomplished with moderate stereoselectivity (runs 1 and 4). After removing the methoxymethyl group of $\mathbf{1 2}$ in an acidic medium, crude diol 13 was treated with PPA to afford a trans/cis mixture of cyclized products $16 \mathbf{a}$ and $\mathbf{1 6} \mathbf{b}$ in $59 \%$ yield in the ratio of $75 / 25$ by HPLC analysis. The trans isomer, $\mathbf{1 6 a}$, was purely isolated by recrystallization from ethanol. Cyclization of triol $\mathbf{1 5}$ under similar conditions as those for 13 gave a mixture of trans and cis isomers (17a and 17b) in the ratio of $88 / 12$. Assuming a half-chair conformation for benzodioxane as shown in Fig. 4 , the coupling constants $(J=7$ and $4 \mathrm{~Hz})$ of the vicinal protons ( $\mathrm{Ha}$ and $\mathrm{Hb}$ ) are in good accord with the reported values $\left(J_{\text {trans }}=6 \mathrm{~Hz}\right.$ and $J_{c i s}=3 \mathrm{~Hz}$ ) for 1,4-benzodioxanes, ${ }^{6)}$ and strongly suggested the stereochemistries as $\mathbf{1 6 a}$ and $\mathbf{1 6 b}$. Due to the anisotropic effect of either the benzene ring at the 3-position or the ester group at the 2-position, the axial protons ( $\mathrm{Ha}$ and $\mathrm{Hb}$ ) of $16 \mathbf{a}$ resonated upfield by 0.32 and $0.31 \mathrm{ppm}$, respectively, from the chemical shift values of the respective protons of $\mathbf{1 6 b}$.

Lithium aluminum hydride reduction of 16a in tetrahydrofuran quantitatively gave alcohol 17a, which, on methylation using methyl iodide and sodium hydride in tetrahydrofuran, gave $\mathbf{2 a}$ in $93 \%$ yield. Compound $\mathbf{2 a}$ was successfully formylated with hexamethylenetetramine in refluxing acetic acid to furnish 6 formyl-7-methoxy-3-methoxymethyl-2-( $3^{\prime}, 4^{\prime}$ methylenedioxyphenyl)-2,3-dihydro-1,4-benzodioxine (4) in $71 \%$ yield. In a conventional Vilsmeier reaction using dimethylformamide and phosphoryl chloride, 2a gave 4 in $28 \%$ yield. 


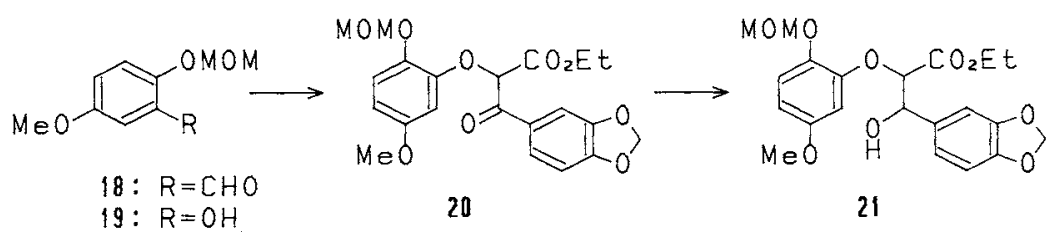

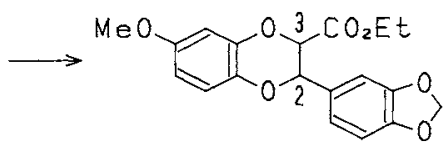

$22 a: 2,3-t r a n s$

$22 b: 2,3$-cis

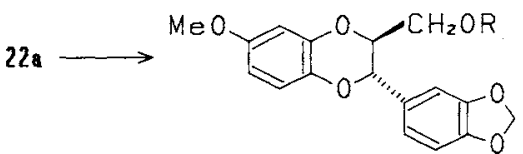

23: $\mathrm{R}=\mathrm{H}$

3: $R=M e$

Fig. 5.

In processes similar to those used for $\mathbf{2 a}$, regioisomer 3 was synthesized from 5-methoxy-2-methoxymethoxybenzaldehyde $(\mathbf{1 8})^{12)}$ in $17 \%$ overall yield (Fig. 5).

With key intermediate 4 at hand, the total syntheses of haedoxan A and D were challenged, details of the work being described in the subsequent paper.

\section{Experimental}

All melting points (mp) and boiling points (bp) are uncorrected. Infrared (IR) spectra were determined on a Shimadzu IR-420 spectrophotometer. ${ }^{1} \mathrm{H}$ - and ${ }^{13} \mathrm{C}$-nuclear magnetic resonance (NMR) spectra were obtained on a JEOL FX-100 spectrometer. Low-resolution electron impact mass spectra (MS) were measured by an ESCO FMD$05 \mathrm{~A}$ spectrometer operated at $70 \mathrm{eV}$.

Gravity column chromatography and flush chromatography were done with Merck silica gel $60(70 \sim 230$ mesh ASTM) and Merck Kieselgel 60G, respectively. High-pressure liquid chromatography (HPLC) was performed with a Shimadzu LC-5A instrument.

2-Hydroxy-4-methoxybenzaldehyde (7). A mixture of 2,4-dihydroxybenzaldehyde $(100 \mathrm{~g}, 0.820 \mathrm{~mol})$, anhydrous $\mathrm{K}_{2} \mathrm{CO}_{3}(100 \mathrm{~g}, 0.725 \mathrm{~mol})$ and methyl iodide $(60 \mathrm{ml}, 0.965$ mol) in acetone (1l) was heated under reflux for $2 \mathrm{hr}$. The mixture was concentrated under reduced pressure, diluted with water, and extracted with ether $(250 \mathrm{ml} \times 2)$. The ethereal layers were combined and extracted twice with $4 \%$ $\mathrm{NaOH}(500 \mathrm{ml} \mathrm{each})$. The aqueous layers were combined, acidified with conc. $\mathrm{HCl}$, and re-extracted with $\mathrm{CH}_{2} \mathrm{Cl}_{2}$. The $\mathrm{CH}_{2} \mathrm{Cl}_{2}$ extract was dried over $\mathrm{Na}_{2} \mathrm{SO}_{4}$, passed through a short silica gel column, and evaporated. The solid residue was recrystallized from $50 \% \mathrm{EtOH}(350 \mathrm{ml})$ to afford $7(63.1 \mathrm{~g}), \mathrm{mp} 41 \sim 42^{\circ} \mathrm{C}$. The mother liquid was diluted with an equal volume of water and cooled to afford another crop of $7(13.1 \mathrm{~g})$; total yield $69 \%$. NMR $\delta_{\mathrm{H}}$ $\left(\mathrm{CDCl}_{3}\right): 3.84(3 \mathrm{H}, \mathrm{s}), 6.24 \sim 6.64(2 \mathrm{H}, \mathrm{m}), 7.40(1 \mathrm{H}, \mathrm{d}, J=$ $8 \mathrm{~Hz}), 9.67(1 \mathrm{H}, \mathrm{s}), 11.44(1 \mathrm{H}, \mathrm{s})$.

4-Methoxy-2-(methoxymethoxy)benzaldehyde (8). A mixture of $7(13.5 \mathrm{~g}, 0.089 \mathrm{~mol})$, pulverized $\mathrm{KOH}(10.0 \mathrm{~g}$, $0.178 \mathrm{~mol})$ and dibenzo-18-crown-6 $(1.0 \mathrm{~g})$ in $\mathrm{CH}_{3} \mathrm{CN}$ $(75 \mathrm{ml})$ was stirred at room temperature for $2 \mathrm{hr}$ before adding chloromethyl methyl ether $(9.0 \mathrm{ml}, 0.116 \mathrm{~mol})$. After $6 \mathrm{hr}$ at room temperature, the mixture was diluted with water $(150 \mathrm{ml})$ and extracted twice with ether $(100 \mathrm{ml}$ and $50 \mathrm{ml}$ ). The ethereal extracts were combined, washed with $5 \% \mathrm{KOH}$, dried over $\mathrm{Na}_{2} \mathrm{SO}_{4}$, and evaporated to give a dark brown oil. The crude product was distilled under reduced pressure to afford $8(13.7 \mathrm{~g}, 0.070 \mathrm{~mol})$ as a colorless oil, bp $126 \sim 127^{\circ} \mathrm{C} / 0.05 \mathrm{mmHg}$, in $79 \%$ yield. NMR $\delta_{\mathrm{H}}\left(\mathrm{CDCl}_{3}\right): 3.50(3 \mathrm{H}, \mathrm{s}), 3.82(3 \mathrm{H}, \mathrm{s}), 5.26(2 \mathrm{H}, \mathrm{s})$, $6.40 \sim 6.72(2 \mathrm{H}, \mathrm{m}), 7.76(1 \mathrm{H}, \mathrm{d}, J=8 \mathrm{~Hz}), 10.26(1 \mathrm{H}, \mathrm{s})$.

4-Methoxy-2-(methoxymethoxy)phenol (9). To a solution of MCPBA $(20.0 \mathrm{~g}, 0.116 \mathrm{~mol})$ in $\mathrm{CH}_{2} \mathrm{Cl}_{2}(500 \mathrm{ml})$, anhydrous $\mathrm{KF}\left(10.1 \mathrm{~g}, 0.174 \mathrm{~mol}\right.$, activated at $100^{\circ} \mathrm{C} \times$ $0.5 \mathrm{mmHg}$ ) was added. The mixture was stirred at room temperature for $30 \mathrm{~min}$ before carefully adding $8(13.6 \mathrm{~g}$, $0.069 \mathrm{~mol}$ ) under cooling in an ice-water bath. After $42 \mathrm{hr}$ at room temperature, the mixture was filtered through a pad of celite with the aid of $\mathrm{CH}_{2} \mathrm{Cl}_{2}$, and the filtrate was concentrated under reduced pressure. To the residue, an aqueous solution of $\mathrm{NaOH}(10.4 \mathrm{~g}, 0.260 \mathrm{~mol} / 300 \mathrm{ml})$ was added, and the resulting mixture was stirred at room temperature for $30 \mathrm{~min}$. The mixture was extracted with ether to remove the unreacted $\mathbf{8}$, before the aqueous layer was acidified with conc. $\mathrm{HCl}$ and extracted with ether $(100 \mathrm{ml} \times 3)$. The ethereal extracts were combined, washed with a mixture of $5 \% \mathrm{NaHCO}_{3}$ and $10 \% \mathrm{Na}_{2} \mathrm{SO}_{3}$, dried over $\mathrm{Na}_{2} \mathrm{SO}_{4}$, and concentrated. The oily residue was distilled under reduced pressure to give $9(9.8 \mathrm{~g}, 0.053 \mathrm{~mol})$ as a colorless oil, bp $102 \sim 107^{\circ} \mathrm{C} / 0.04 \mathrm{mmHg}$, in $77 \%$ 
yield. NMR $\delta_{\mathrm{H}}\left(\mathrm{CDCl}_{3}\right): 3.33(3 \mathrm{H}, \mathrm{s}), 3.57(3 \mathrm{H}, \mathrm{s}), 5.00$ $(2 \mathrm{H}, \mathrm{s}), 5.51(1 \mathrm{H}, \mathrm{br}), 6.31(1 \mathrm{H}, \mathrm{dd}, J=9,3 \mathrm{~Hz}), 6.55(1 \mathrm{H}$, d, $J=3 \mathrm{~Hz}), 6.68(1 \mathrm{H}, \mathrm{d}, J=9 \mathrm{~Hz})$. IR $v_{\max }$ (neat) $\mathrm{cm}^{-1}$ : $990,1077,1152,1225,1505,1612,3450$.

Methyl 2-bromo-2-(3',4'-methylenedioxybenzoyl)acetate (10). To a solution of methyl 3,4-methylenedioxybenzoylacetate ${ }^{10)}(17.0 \mathrm{~g}, 0.077 \mathrm{~mol})$ in $\mathrm{CHCl}_{3}(75 \mathrm{ml})$, bromine $(4.0 \mathrm{ml}, 0.078 \mathrm{~mol})$ dissolved in $\mathrm{CHCl}_{3}(40 \mathrm{ml})$ was added dropwise while keeping the temperature below $20^{\circ} \mathrm{C}$. After the addition has been completed, the mixture was washed successively with water, $5 \% \mathrm{NaHCO}_{3}, 10 \%$ $\mathrm{Na}_{2} \mathrm{SO}_{3}$ and again water. The organic layer was dried over $\mathrm{Na}_{2} \mathrm{SO}_{4}$ and evaporated to give $10(22.9 \mathrm{~g}, 0.076 \mathrm{~mol})$ as a viscous yellow oil in $97 \%$ yield. This was used for the next step without further purification.

Methyl 2-\{4'-methoxy-2'-(methoxymethyl)phenoxy\}-3(3", $4^{\prime \prime}$-methylenedioxyphenyl)-3-oxopropionate (11). A mixture of phenol $9(9.2 \mathrm{~g}, 0.050 \mathrm{~mol})$, tert-BuOK $(6.0 \mathrm{~g}$, $0.053 \mathrm{~mol})$ and dibenzo-18-crown-6 $(1.8 \mathrm{~g}, 5 \mathrm{mmol})$ in dry $\mathrm{CH}_{3} \mathrm{CN}(130 \mathrm{ml})$ was stirred at room temperature for $2 \mathrm{hr}$. A solution of bromide $10(19.0 \mathrm{~g}, 0.063 \mathrm{~mol})$ in $\mathrm{CH}_{3} \mathrm{CN}$ $(15 \mathrm{ml})$ was then added to the mixture, and stirring was continued for another $14 \mathrm{hr}$ at room temperature. The mixture was poured into water $(600 \mathrm{ml})$ and extracted with EtOAc $(120 \mathrm{ml} \times 3)$. The organic layers were combined, washed successively with $0.5 \mathrm{~N} \mathrm{NaOH}, 5 \% \mathrm{NaHCO}_{3}$ and brine, dried over $\mathrm{Na}_{2} \mathrm{SO}_{4}$, and evaporated. The oily residue was chromatographed on silica gel with iso- $\mathrm{Pr}_{2} \mathrm{O}-$ benzene $(1: 3)$ as the eluant to give $11(18.9 \mathrm{~g}, 0.047 \mathrm{~mol})$ as a viscous oil in $94 \%$ yield. $\mathrm{NMR} \delta_{\mathrm{H}}\left(\mathrm{CDCl}_{3}\right): 3.43(3 \mathrm{H}, \mathrm{s})$, $3.71(3 \mathrm{H}, \mathrm{s}), 3.77(3 \mathrm{H}, \mathrm{s}), 5.11(2 \mathrm{H}, \mathrm{s}), 5.59(1 \mathrm{H}, \mathrm{s}), 6.01$ $(2 \mathrm{H}, \mathrm{s}), 6.37(1 \mathrm{H}, \mathrm{dd}, J=9,3 \mathrm{~Hz}), 6.69(1 \mathrm{H}, \mathrm{d}, J=3 \mathrm{~Hz})$, $6.82(1 \mathrm{H}, \mathrm{d}, J=9 \mathrm{~Hz}), 6.94(1 \mathrm{H}, \mathrm{d}, J=9 \mathrm{~Hz}), 7.59(1 \mathrm{H}, \mathrm{d}$, $J=2 \mathrm{~Hz}), 7.79(\mathrm{IH}, \mathrm{dd}, J=9,2 \mathrm{~Hz})$. IR $v_{\max }\left(\mathrm{CHCl}_{3}\right)$ $\mathrm{cm}^{-1}: 800,1030,1075,1160,1205,1250,1445,1560,1745$. MS $m / z: 404\left(\mathrm{M}^{+}\right), 150,149$ (base), 121, 65.

Methyl 3-hydroxy-2-\{4'-methoxy-2'-(methoxyme-

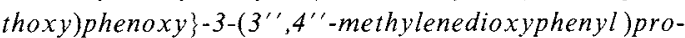
pionate (12). To a solution of $11(6.7 \mathrm{~g}, 16.6 \mathrm{mmol})$ in a mixture of EtOH $(20 \mathrm{ml})$ and THF $(20 \mathrm{ml}), \mathrm{NaBH}_{4}(0.3 \mathrm{~g}$, $7.9 \mathrm{mmol})$ dissolved in EtOH $(20 \mathrm{ml})$ was added dropwise at $-10^{\circ} \mathrm{C}$. The solution was stirred at $-10^{\circ} \mathrm{C}$ for $45 \mathrm{~min}$ and gradually warmed up to room temperature over a period of $45 \mathrm{~min}$. The mixture was then acidified ( $\mathrm{pH} 6)$ with $2 \mathrm{~N} \mathrm{HCl}$, concentrated under reduced pressure, and extracted with EtOAc. The organic layer was washed with $5 \% \mathrm{NaHCO}_{3}$, dried over $\mathrm{Na}_{2} \mathrm{SO}_{4}$, and evaporated. The oily residue was chromatographed on silica gel with benzene-EtOAc $(4: 1)$ as the eluant to give $12(3.6 \mathrm{~g}$, $8.9 \mathrm{mmol})$ as a viscous oil in $53 \%$ yield. NMR $\delta_{\mathrm{H}}\left(\mathrm{CDCl}_{3}\right)$ $3.48(3 \mathrm{H}, \mathrm{s}), 3.67(3 \mathrm{H}, \mathrm{s}), 3.72(3 \mathrm{H}, \mathrm{s}), 3.64 \sim 3.95(1 \mathrm{H}, \mathrm{br}$ ) , $4.61(1 \mathrm{H}, \mathrm{d}, J=6 \mathrm{~Hz}), 4.87 \sim 5.10(1 \mathrm{H}, \mathrm{br}),. 5.15(2 \mathrm{H}, \mathrm{s})$, $5.91(2 \mathrm{H}, \mathrm{s}), 6.38(1 \mathrm{H}, \mathrm{dd}, J=9,4 \mathrm{~Hz}), 6.60 \sim 7.00(5 \mathrm{H}, \mathrm{m})$. Compound 12 was followed by the elution of another compound $(14 ; 1.75 \mathrm{~g}, 4.5 \mathrm{mmol})$ in $27 \%$ yield

2-\{(2'-Hydroxy-4'-methoxy)phenoxy $\}-1-\left(3^{\prime \prime}, 4^{\prime \prime}-\right.$ methylenedioxyphenyl)-1,3-propanediol (15). A solution of 11 $(22.3 \mathrm{~g}, 0.055 \mathrm{~mol})$ and $\mathrm{NaBH}_{4}(2.1 \mathrm{~g}, 0.055 \mathrm{~mol})$ in a mixture of THF $(100 \mathrm{ml})$ and $\mathrm{EtOH}(100 \mathrm{ml})$ was stirred at room temperature for $20 \mathrm{hr}$. The mixture was acidified ( $\mathrm{pH}$ 2) with $2 \mathrm{~N} \mathrm{HCl}$ and allowed to stand at room temperature for 2 days before being concentrated under reduced pressure. The residue was taken up in EtOAc, washed with brine, and dried over $\mathrm{Na}_{2} \mathrm{SO}_{4}$. After removing the solvent, the residue was purified by flush chromatography on silica gel. Elution with $n$-hexane-EtOAc $(2: 1-1: 1)$ afforded 15 $(13.4 \mathrm{~g}, 0.040 \mathrm{~mol})$ as a viscous oil in $73 \%$ yield. NMR $\delta_{\mathrm{H}}$ $\left(\mathrm{CDCl}_{3}\right): 2.00 \sim 3.20(3 \mathrm{H}$, br. $), 3.50 \sim 4.00(3 \mathrm{H}, \mathrm{m}), 3.72$ $(3 \mathrm{H}, \mathrm{s}), 4.99(1 \mathrm{H}, \mathrm{d}, J=4 \mathrm{~Hz}), 5.92(2 \mathrm{H}, \mathrm{s}), 6.29(1 \mathrm{H}, \mathrm{dd}$, $J=3,9 \mathrm{~Hz}), 6.47(1 \mathrm{H}, \mathrm{d}, J=3 \mathrm{~Hz}), 6.63 \sim 6.92(4 \mathrm{H}, \mathrm{m})$. IR $v_{\max }\left(\mathrm{CHCl}_{3}\right) \mathrm{cm}^{-1}: 1040,1160,1240,1445,1490,1505$, 1595, 3350. MS $m / z: 334\left(\mathrm{M}^{+}\right), 166,151,149,140$ (base), $125,111,93,65$

6-Methoxy-2-methoxycarbonyl-3-(3',4'-methylenedioxyphenyl)-2,3-dihydro-1,4-benzodioxines (16a/16b). A solution of $12(13.1 \mathrm{~g}, 0.032 \mathrm{~mol})$ in $\mathrm{MeOH}(200 \mathrm{ml})$ containing a few drops of conc. $\mathrm{HCl}$ was heated under reflux for $30 \mathrm{~min}$. After cooling to room temperature, the mixture was concentrated under reduced pressure to give crude 13. The crude product was mixed with PPA $(86.7 \mathrm{~g})$ for a few minutes and the mixture was partitioned between cold water and EtOAc. The organic layer was washed with $5 \% \mathrm{NaHCO}_{3}$, dried over $\mathrm{Na}_{2} \mathrm{SO}_{4}$, and evaporated. The residue was chromatographed on silica gel with iso- $\mathrm{Pr}_{2} \mathrm{O}-$ benzene $(1: 5)$ as the eluant to give a mixture of $16 \mathbf{a}$ and $\mathbf{1 6 b}(6.4 \mathrm{~g}, 0.019 \mathrm{~mol})$ in $59 \%$ yield. The ratio of $\mathbf{1 6 a} / \mathbf{1 6 b}$ was determined at $75 / 25$ by HPLC analysis [Zorbax-SIL column, $25 \mathrm{~cm} \times 4.6 \mathrm{~mm}$; $n$-hexane-ether $(3: 1), 1 \mathrm{ml} / \mathrm{min}$ ]. Compound 16a (trans isomer) was obtained by recrystallization from EtOH, mp $110 \sim 112^{\circ} \mathrm{C}$. NMR $\delta_{\mathrm{H}}\left(\mathrm{CDCl}_{3}\right)$ : $3.62(3 \mathrm{H}, \mathrm{s}), 3.71(3 \mathrm{H}, \mathrm{s}), 4.55(1 \mathrm{H}, \mathrm{d}, J=7 \mathrm{~Hz}), 5.07(1 \mathrm{H}$, $\mathrm{d}, J=7 \mathrm{~Hz}), 5.95(2 \mathrm{H}, \mathrm{s}), 6.32 \sim 6.52(2 \mathrm{H}, \mathrm{m}), 6.88 \sim 6.98$ $(4 \mathrm{H}, \mathrm{m}) . \mathrm{IR} v_{\max }(\mathrm{KBr}) \mathrm{cm}^{-1}: 1745,1500,1445,1250$, $1205,1160,1075,1030,800$. MS $m / z: 345\left(\mathrm{M}^{+}\right), 208,206$ (base), 176, 145, 89. Anal. Found: C, 62.76; H, 4.72. Calcd. for $\mathrm{C}_{18} \mathrm{H}_{16} \mathrm{O}_{7}: \mathrm{C}, 62.79 ; \mathrm{H}, 4.65 \%$.

16b (cis isomer). Viscous oil. NMR $\delta_{\mathrm{H}}\left(\mathrm{CDCl}_{3}\right): 3.60$ $(3 \mathrm{H}, \mathrm{s}), 3.72(3 \mathrm{H}, \mathrm{s}), 4.86(1 \mathrm{H}, \mathrm{d}, J=4 \mathrm{~Hz}), 5.35(1 \mathrm{H}, \mathrm{d}$, $J=4 \mathrm{~Hz}), 5.90(2 \mathrm{H}, \mathrm{s}), 6.32 \sim 6.54(2 \mathrm{H}, \mathrm{m}), 6.68 \sim 6.95$ $(4 \mathrm{H}, \mathrm{m})$

2-Hydroxymethyl-6-methoxy-3-(3',4'-methylenedioxyphenyl)-2,3-dihydro-1,4-benzodioxines (17a/17b). Triol $15(13.0 \mathrm{~g}, 0.039 \mathrm{~mol})$ was mixed well with PPA $(93 \mathrm{~g})$ at room temperature for a few minutes. Cold water was then added and the mixture was extracted twice with EtOAc $(200 \mathrm{ml}$ each). The combined organic layers were washed successively with brine and $5 \% \mathrm{NaHCO}_{3}$, dried over $\mathrm{Na}_{2} \mathrm{SO}_{4}$, and concentrated. The residue was purified by 
flush chromatography on silica gel with $n$-hexane-EtOAc ( $3: 1$ ) as the eluant to give an $88 / 12$ mixture (determined by HPLC) of $17 \mathrm{a}$ and $17 \mathrm{~b}(7.36 \mathrm{~g}, 0.023 \mathrm{~mol})$ in $60 \%$ yield. The trans isomer $(\mathbf{1 7 a} ; 6.29 \mathrm{~g}, 51 \%)$ was obtained by trituration with ether, mp $73 \sim 75^{\circ} \mathrm{C}$. NMR $\delta_{\mathrm{H}}\left(\mathrm{CDCl}_{3}\right)$ : 2.92 (1H, br.), 3.50 (1H, dd, $J=12,4 \mathrm{~Hz}), 3.72(3 \mathrm{H}, \mathrm{s})$, $3.71 \sim 4.02(3 \mathrm{H}, \mathrm{m}), 4.90(\mathrm{HH}, \mathrm{d}, J=8 \mathrm{~Hz}), 5.96(2 \mathrm{H}, \mathrm{s})$, $6.32 \sim 6.54(2 \mathrm{H}, \mathrm{m}), 6.68 \sim 6.95(4 \mathrm{H}, \mathrm{m}) . \mathrm{IR} v_{\max }(\mathrm{KBr})$ $\mathrm{cm}^{-1}: 797,817,1030,1042,1160,1232,1500,3500$. MS $m / z: 316\left(\mathrm{M}^{+}\right), 178,150,135$ (base), 148, 91, 89, 69, 52. Anal. Found: $\mathrm{C}, 64.44 ; \mathrm{H}, 5.16$. Calcd. for $\mathrm{C}_{17} \mathrm{H}_{16} \mathrm{O}_{6}: \mathrm{C}$, $64.56 ; \mathrm{H}, 5.06 \%$.

6-Methoxy-2-methoxymethyl-3-(3',4'-methylenedioxyphenyl)-2,3-dihydro-1,4-benzodioxine $(\mathbf{2 a} / \mathbf{2 b})$. A solution of $16 \mathrm{a}$ (490 $\mathrm{mg}, 1.4 \mathrm{mmol}$ ) dissolved in dry THF $(10 \mathrm{ml})$ was added dropwise to a stirred slurry of $\mathrm{LiAlH}_{4}(60 \mathrm{mg}$, $1.6 \mathrm{mmol})$ in THF $(10 \mathrm{ml})$ at $-10^{\circ} \mathrm{C}$. After $15 \mathrm{~min}$, the excess hydrides were decomposed by carefully adding EtOAc and then $0.5 \mathrm{~N} \mathrm{HCl}$. The mixture was extracted with ether, washed with brine, dried over $\mathrm{Na}_{2} \mathrm{SO}_{4}$, and evaporated to give crude $\mathbf{1 7} \mathbf{a}$ as white crystals.

A solution of crude alcohol $17 \mathbf{a}$ in dry THF $(10 \mathrm{ml})$ was added dropwise to a stirred slurry of $\mathrm{NaH}(60 \%$ in oil, $84 \mathrm{mg}, 2.1 \mathrm{mmol})$ in THF $(10 \mathrm{ml})$ at $-10^{\circ} \mathrm{C}$. After $45 \mathrm{~min}$, methyl iodide $(0.2 \mathrm{ml}, 3.2 \mathrm{mmol})$ was added to the mixture, and stirring was continued for another $2 \mathrm{hr}$ at room temperature. The reaction was then quenched by a few drops of $\mathrm{MeOH}$, before the mixture was partitioned between ether and $0.5 \mathrm{~N} \mathrm{HCl}$. The ethereal layer was separated, washed with brine, dried over $\mathrm{Na}_{2} \mathrm{SO}_{4}$, and evaporated. The oily residue was chromatographed on silica gel eluted with iso- $\mathrm{Pr}_{2} \mathrm{O}$ to afford $2 \mathrm{a}(429 \mathrm{mg}$, $1.3 \mathrm{mmol}$ ), mp $128 \sim 129^{\circ} \mathrm{C}$, in $93 \%$ yield. NMR $\delta_{\mathrm{H}}$ $\left(\mathrm{CDCl}_{3}\right): 3.27(\mathrm{lH}$, dd, $J=10,5 \mathrm{~Hz}), 3.32(3 \mathrm{H}, \mathrm{s}), 3.55$ (1H, dd, $J=10,3 \mathrm{~Hz}), 3.71(3 \mathrm{H}, \mathrm{s}), 3.96(1 \mathrm{H}, \mathrm{m}), 4.95(1 \mathrm{H}$, d, $J=8 \mathrm{~Hz}), 5.96(2 \mathrm{H}, \mathrm{s}), 6.30 \sim 6.53(2 \mathrm{H}, \mathrm{m}), 6.70 \sim 7.00$ $(4 \mathrm{H}, \mathrm{m}) . \mathrm{IR} v_{\max }(\mathrm{KBr}) \mathrm{cm}^{-1}: 1505,1490,1275,1250$, $1245,1125,1030$. MS $m / z: 330\left(\mathrm{M}^{+}\right.$, base $), 299,258,193$, 161, 132, 103. NMR $\delta_{\mathrm{C}}\left(\mathrm{CDCl}_{3}\right): 55.6(\mathrm{q}), 59.4(\mathrm{q}), 71.2(\mathrm{t})$, 76.4 (d), 77.1 (d), 101.3 (t), 102.4 (d), 107.4 (d), 107.6 (d), 108.4 (d), 117.4 (d), 121.2 (d), $130.4(\mathrm{~s}), 137.3$ (s), 143.9 (s), $148.0(\mathrm{~s} \times 2), 154.2(\mathrm{~s})$. UV $\lambda_{\max }\left(\mathrm{CHCl}_{3}\right) \cdot \mathrm{nm}(\varepsilon): 246$ $(5,530), 291(8,840)$. Anal. Found: C, 65.33; H, 5.51. Calcd. for $\mathrm{C}_{18} \mathrm{H}_{18} \mathrm{O}_{6}: \mathrm{C}, 65.45 ; \mathrm{H}, 5.45 \%$.

By the same procedure, oily $\mathbf{2 b}$ was obtained from $\mathbf{1 6 b}$. $\mathrm{NMR} \delta_{\mathrm{H}}\left(\mathrm{CDCl}_{3}\right): 3.23(1 \mathrm{H}, \mathrm{dd}, J=4,11 \mathrm{~Hz}), 3.28(3 \mathrm{H}, \mathrm{s})$, $3.45(1 \mathrm{H}, \mathrm{dd}, J=8,11 \mathrm{~Hz}), 3.74(3 \mathrm{H}, \mathrm{s}), 4.50(1 \mathrm{H}, \mathrm{m}), 5.17$ $(1 \mathrm{H}, \mathrm{d}, J=3 \mathrm{~Hz}), 5.94(2 \mathrm{H}, \mathrm{s}), 6.39 \sim 6.57(2 \mathrm{H}, \mathrm{m}), 6.75 \sim$ $6.98(4 \mathrm{H}, \mathrm{m})$.

7-Formyl-6-methoxy-2-methoxymethyl-3-(3',4'-methylenedioxyphenyl)-2,3-dihydro-1,4-benzodioxine (4).

Duff reaction. A solution of $\mathbf{2 a}(0.31 \mathrm{~g}, 0.94 \mathrm{mmol})$ and hexamethylenetetramine $(0.15 \mathrm{~g}, 1.07 \mathrm{mmol})$ in $\mathrm{AcOH}(20$ $\mathrm{ml})$ was heated under reflux for $16 \mathrm{hr}$. After cooling to room temperature, water was added to the reaction mix- ture. After $1 \mathrm{hr}$ at room temperature, the mixture was concentrated under reduced pressure. The residue was taken up in EtOAc, washed successively with water and $5 \% \mathrm{NaHCO}_{3}$, dried over $\mathrm{Na}_{2} \mathrm{SO}_{4}$, and evaporated. The oily residue was chromatographed on silica gel with $n$ hexane-EtOAc $(3: 1)$ as the eluant to afford $4(0.24 \mathrm{~g}$, $0.67 \mathrm{mmol}$ ) as pale yellow powder in $71 \%$ yield.

Vilsmeier method. To a cold $\left(c .5^{\circ} \mathrm{C}\right)$ solution of $\mathbf{2 a}$ $(548 \mathrm{mg}, 1.66 \mathrm{mmol})$ in dry DMF $(5 \mathrm{ml})$ was added $\mathrm{POCl}_{3}$ $(0.23 \mathrm{ml}, 2.5 \mathrm{mmol})$ in one portion, before the mixture was heated at $60 \sim 65^{\circ} \mathrm{C}$ for $1 \mathrm{hr}$. After cooling, saturated aqueous AcONa $(5 \mathrm{ml})$ was added, and the mixture was heated on a steam bath for $30 \mathrm{~min}$. After cooling, the mixture was diluted with water and the precipitated solids were collected. The solids were dissolved in EtOAc, washed with brine, dried over $\mathrm{Na}_{2} \mathrm{SO}_{4}$, and concentrated. The residue was chromatographed on silica gel eluted with benzene-EtOAc $(95: 5)$ to give 4 (166 $\mathrm{mg}, 0.46 \mathrm{mmol})$ in $28 \%$ yield along with $69 \%$ recovery of $2 \mathrm{a}$. NMR $\delta_{\mathrm{H}}$ $\left(\mathrm{CDCl}_{3}\right): 3.28(1 \mathrm{H}, \mathrm{dd}, J=11,5 \mathrm{~Hz}), 3.33(3 \mathrm{H}, \mathrm{s}), 3.60$ $(1 \mathrm{H}, \mathrm{dd}, J=11,3 \mathrm{~Hz}), 3.81(3 \mathrm{H}, \mathrm{s}), 3.96(1 \mathrm{H}, \mathrm{m}), 5.06(1 \mathrm{H}$, $\mathrm{d}, J=8 \mathrm{~Hz}), 5.98(2 \mathrm{H}, \mathrm{s}), 6.51(1 \mathrm{H}, \mathrm{s}), 6.85(3 \mathrm{H}, \mathrm{s}), 7.45$ $(1 \mathrm{H}, \mathrm{s}), 10.22(\mathrm{HH}, \mathrm{s})$. IR $v_{\max }\left(\mathrm{CHCl}_{3}\right) \mathrm{cm}^{-1}: 1020,1128$, $1245,1308,1495,1590,1620,1675$. UV $\lambda_{\max }\left(\mathrm{CHCl}_{3}\right) \mathrm{nm}$ (ع): $245(15,230), 279$ (14,840), 342 (8200). Anal. Found: C, $63.32 ; \mathrm{H}, 5.11$. Calcd. for $\mathrm{C}_{19} \mathrm{H}_{18} \mathrm{O}_{7}: \mathrm{C}, 63.68 ; \mathrm{H}, 5.03 \%$.

5-Methoxy-2-(methoxymethoxy)phenol (19). A colorless oil, $70 \%$ yield, bp $130^{\circ} \mathrm{C}$ (bath) $/ 0.03 \mathrm{mmHg}$. NMR $\delta_{\mathrm{H}}$ $\left(\mathrm{CDCl}_{3}\right): 3.50(3 \mathrm{H}, \mathrm{s}), 3.72(3 \mathrm{H}, \mathrm{s}), 5.07(2 \mathrm{H}, \mathrm{s}), 6.18(1 \mathrm{H}$, s), $6.31(1 \mathrm{H}, \mathrm{dd}, J=3,10 \mathrm{~Hz}), 6.51(1 \mathrm{H}, \mathrm{d}, J=3 \mathrm{~Hz}), 6.94$ $(1 \mathrm{H}, \mathrm{d}, J=10 \mathrm{~Hz})$. MS $m / z: 184\left(\mathrm{M}^{+}\right), 139,46,33,29$ (base).

Ethyl 2-\{5'-methoxy-2'-(methoxymethoxy)phenoxy $\}-3-$ $\left(3^{\prime \prime}, 4^{\prime \prime}\right.$-methylenedioxyphenyl)-3-oxopropionate (20). A pale yellow oil, $90 \%$ yield. NMR $\delta_{\mathrm{H}}\left(\mathrm{CDCl}_{3}\right): 1.22(3 \mathrm{H}, \mathrm{t}$, $J=7 \mathrm{~Hz}), 3.44(3 \mathrm{H}, \mathrm{s}), 3.69(3 \mathrm{H}, \mathrm{s}), 4.23(2 \mathrm{H}, \mathrm{q}, J=7 \mathrm{~Hz})$, $5.04(2 \mathrm{H}, \mathrm{s}), 5.69(1 \mathrm{H}, \mathrm{s}), 6.60(2 \mathrm{H}, \mathrm{s}), 6.28 \sim 6.60(2 \mathrm{H}, \mathrm{m})$, $6.81(1 \mathrm{H}, \mathrm{d}, J=8 \mathrm{~Hz}), 7.00(1 \mathrm{H}, \mathrm{d}, J=2 \mathrm{~Hz}), 7.54(1 \mathrm{H}, \mathrm{d}$, $J=2 \mathrm{~Hz}), 7.76(1 \mathrm{H}, \mathrm{dd}, J=8,2 \mathrm{~Hz})$.

Ethyl 3-hydroxy-2-\{5'-methoxy-2'-(methoxymethoxy)phenoxy\}-3-(3'",4"-methylenedioxyphenyl)propionate (21). A pale yellow oil, $63 \%$ yield. NMR $\delta_{\mathrm{H}}\left(\mathrm{CDCl}_{3}\right): 1.15$ $(3 \mathrm{H}, \mathrm{t}, J=7 \mathrm{~Hz}), 3.49(3 \mathrm{H}, \mathrm{s}), 3.54 \sim 3.82(1 \mathrm{H}, \mathrm{br}), 3.69$ $(3 \mathrm{H}, \mathrm{s}), 4.12(2 \mathrm{H}, \mathrm{q}, J=7 \mathrm{~Hz}), 4.70(1 \mathrm{H}, \mathrm{d}, J=7 \mathrm{~Hz})$, $4.88 \sim 5.16(3 \mathrm{H}, \mathrm{m}), 5.90(2 \mathrm{H}, \mathrm{s}), 6.30 \sim 6.58(2 \mathrm{H}, \mathrm{m})$, $6.62 \sim 6.86(2 \mathrm{H}, \mathrm{m}), 6.88 \sim 7.06(2 \mathrm{H}, \mathrm{m})$.

3-Ethoxycarbonyl-6-methoxy-2-(3',4'-methylenedioxyphenyl)-2,3-dihydro-1,4-benzodioxines (22a/22b). $64 \%$ yield, 22a/22b $=72 / 28$ (determined by HPLC). 2,3-trans22a. White crystals, mp $131 \sim 133^{\circ} \mathrm{C} . \mathrm{NMR} \delta_{\mathrm{H}}\left(\mathrm{CDCl}_{3}\right)$ : $1.08(3 \mathrm{H}, \mathrm{t}, J=7 \mathrm{~Hz}), 3.72(3 \mathrm{H}, \mathrm{s}), 4.08(2 \mathrm{H}, \mathrm{q}, J=7 \mathrm{~Hz})$, $4.17(1 \mathrm{H}, \mathrm{d}, J=7 \mathrm{~Hz}), 4.98(1 \mathrm{H}, \mathrm{d}, J=7 \mathrm{~Hz}), 5.94(2 \mathrm{H}, \mathrm{s})$, $6.32 \sim 6.64(2 \mathrm{H}, \mathrm{m}), 6.64 \sim 6.96(4 \mathrm{H}, \mathrm{m}) . \mathrm{MS} m / z: 358$ 
$\left(\mathrm{M}^{+}\right), 312,286,220$ (base), 175, 148, 89. Anal. Found: C, $63.69 ; \mathrm{H}, 5.09$. Calcd. for $\mathrm{C}_{19} \mathrm{H}_{18} \mathrm{O}_{7}: \mathrm{C}, 63.69 ; \mathrm{H}, 5.03 \%$. 2,3-cis-22b. A viscous oil. NMR $\delta_{\mathrm{H}}\left(\mathrm{CDCl}_{3}\right): 1.07(3 \mathrm{H}, \mathrm{t}$, $J=7 \mathrm{~Hz}), 3.72(3 \mathrm{H}, \mathrm{s}), 4.05(2 \mathrm{H}, \mathrm{q}, J=7 \mathrm{~Hz}), 4.88(1 \mathrm{H}, \mathrm{d}$, $J=3 \mathrm{~Hz}), 5.28(1 \mathrm{H}, \mathrm{d}, J=3 \mathrm{~Hz}), 5.91(2 \mathrm{H}, \mathrm{s}), 6.32 \sim 6.64$ $(2 \mathrm{H}, \mathrm{m}), 6.64 \sim 6.96(4 \mathrm{H}, \mathrm{m})$.

3-Hydroxymethyl-6-methoxy-2-(3',4'-methylenedioxyphenyl)-2,3-dihydro-1,4-benzodioxine (23). White crystals, $99 \%$ yield, mp $128 \sim 129^{\circ} \mathrm{C}$. NMR $\delta_{\mathrm{H}}\left(\mathrm{CDCl}_{3}\right): 1.94 \sim 2.15$ (1H, br.), $3.39 \sim 3.91(2 \mathrm{H}, \mathrm{m}), 3.76(3 \mathrm{H}, \mathrm{s}), 3.91 \sim 4.09$ $(1 \mathrm{H}, \mathrm{m}), 4.87(1 \mathrm{H}, \mathrm{d}, J=9 \mathrm{~Hz}), 5.98(2 \mathrm{H}, \mathrm{s}), 6.45(1 \mathrm{H}, \mathrm{dd}$, $J=9,3 \mathrm{~Hz}), 6.55(1 \mathrm{H}, \mathrm{d}, J=2 \mathrm{~Hz}), 6.73 \sim 7.04(4 \mathrm{H}, \mathrm{m})$.

6-Methoxy-3-methoxymethyl-2-(3',4'-methylenedioxyphenyl)-2,3-dihydro-1,4-benzodioxine (3). White crystals, $93 \%$ yield, mp $96^{\circ} \mathrm{C}$. NMR $\delta_{\mathrm{H}}\left(\mathrm{CDCl}_{3}\right): 3.26(1 \mathrm{H}, \mathrm{dd}, J=$ $5,11 \mathrm{~Hz}), 3.34(3 \mathrm{H}, \mathrm{s}), 3.54(1 \mathrm{H}, \mathrm{dd}, J=3,11 \mathrm{~Hz}), 3.73$ $(3 \mathrm{H}, \mathrm{s}), 4.04(1 \mathrm{H}, \mathrm{m}), 4.87(1 \mathrm{H}, \mathrm{d}, J=9 \mathrm{~Hz}), 5.96(2 \mathrm{H}, \mathrm{s})$, $6.40(1 \mathrm{H}, \mathrm{dd}, J=3,9 \mathrm{~Hz}), 6.56(1 \mathrm{H}, \mathrm{d}, J=3 \mathrm{~Hz}), 6.72 \sim$ $6.94(3 \mathrm{H}, \mathrm{m}) . \mathrm{NMR} \delta_{\mathrm{C}}\left(\mathrm{CDCl}_{3}\right): 55.5(\mathrm{q}), 59.3(\mathrm{q}), 71.2(\mathrm{t})$, 75.9 (d), 77.6 (d), 101.2 (t), 102.3 (d), 107.3 (d), 107.6 (d), 108.3 (d), 117.1 (d), 121.2 (d), $130.5(\mathrm{~s}), 137.7(\mathrm{~s}), 143.5(\mathrm{~s})$, $148.0(\mathrm{~s} \times 2), 154.3(\mathrm{~s})$.

\section{References}

1) I. Mittel, A. Pelter and R. Hänsel, Chem. Ber., 108 , 790 (1975).

2) W. S. Woo, S. S. Kang, H. Wagner and V. M. Chari, Tetrahedron Lett., 1978, 3239.

3) A. B. Ray, S. K. Charttopadhyay, C. Kondo and H. Hikino, Tetrahedron Lett., 21, 4477 (1980).

4) E. Taniguchi, K. Imamura, F. Ishibashi, T. Matsui and A. Nishio, Agric. Biol. Chem., 53, 631 (1989).

5) T.-L. Su, T. Schulz and R. Hänsel, Chem. Ber., 110, 3867 (1977).

6) R. Hänsel, T.-L. Su and T. Schultz, Chem. Ber., 110, 3664 (1977).

7) H. Tanaka, I. Kato and K. Kato, Chem. Pharm. Bull., 35, 3603 (1987).

8) G. N. Vyas and N. M. Shah, Org. Synth., Coll. Vol., IV, 836 (1963).

9) F. Champs, J. Coll, A Messeguer and M. A. Pericas, Tetrahedron Lett., 22, 3895 (1981).

10) F. v. Bruchhausen and H. Gerhard, Chem. Ber., 72, 830 (1939).

11) A. Arnoldi, L. Camarda and L. Merlini, J. Agric. Food. Chem., 34, 339 (1986).

12) N. S. Narasimhan, R. S. Mali and M. V. Brave, Synthesis, 1979, 906. 